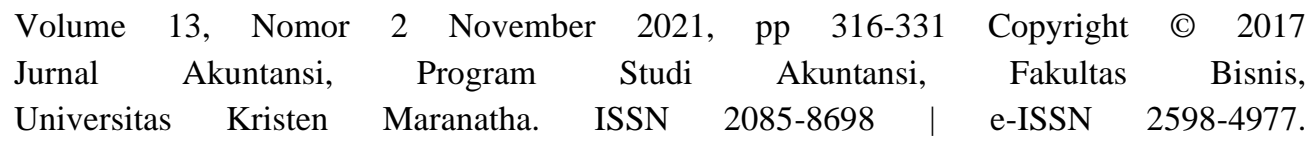

http://journal.maranatha.edu

\title{
Sisa Lebih Pembiayaan Anggaran Sebagai Pemoderasi Antara Dana Perimbangan, Dana Bagi Hasil, dan Pajak Daerah Terhadap Belanja Modal
}

\author{
Dirvi Surya Abbas ${ }^{1}$ \\ Program Studi S1 Akuntansi, Fakultas Ekonomi dan Bisnis, \\ Universitas Muhammadiyah Tangerang \\ abbas.dirvi@gmail.com \\ Savira Yenita Sari ${ }^{2}$ \\ Program Studi S1 Akuntansi, Fakultas Ekonomi dan Bisnis, \\ Universitas Muhammadiyah Tangerang \\ savirayenitasari05@gmail.com \\ Mohamad Zulman Hakim ${ }^{3}$ \\ Program Studi S1 Akuntansi, Fakultas Ekonomi dan Bisnis, \\ Universitas Muhammadiyah Tangerang \\ Zulman.hakim@umt.ac.id \\ Hesty Erviani Zulaecha ${ }^{4}$ \\ Program Studi S1 Akuntansi, Fakultas Ekonomi dan Bisnis, \\ Universitas Muhammadiyah Tangerang \\ Hestyerviani2005@gmail.com \\ Dewi Rachmania ${ }^{5}$ \\ Program Studi S1 Akuntansi, Fakultas Ekonomi dan Bisnis, \\ Universitas Muhammadiyah Tangerang \\ dewi.rachmania78@gmail.com
}

\begin{abstract}
This research aims to determine the effect of compensation funds, revenue-sharing funds and local taxes on capital expenditures in districts or cities in the province of Banten. Observation time in this research is for six years, namely 2015 to 2020. The object of observation in this study is all districts or cities in Banten Province. The sampling technique used is intentional (purposive) sampling. This study uses secondary data obtained from the Realization Report of the Regional Revenue and Expenditure Budget. The method of analysis used panel data regression analysis. The results of the research explain that the Balancing Fund has a negative and insignificant effect on capital expenditure, the Profit
\end{abstract}


Sharing Fund has a negative and significant effect on capital expenditure, Regional Taxes have a positive and insignificant effect on capital expenditure, while the remaining excess budget financing has a negative and significant impact on Expenditures. Capital, Remaining Budget Financing is able to moderate and able to strengthen or weaken the relationship between Balancing Funds to Capital Expenditures, Remaining Budget Financing is able to moderate and able to strengthen the relationship between Profit Sharing Funds to Capital Expenditures, and Remaining Funding Budgets are unable to moderate and are unable to strengthen or weaken the relationship between Regional Taxes and Capital Expenditures.

\title{
Keywords: Capital Expenditures, Balancing Funds, Profit Sharing Funds, Regional Taxes, and Remaining Budget Financing
}

\begin{abstract}
Abstrak
Riset ini bertujuan untuk mengetahui pengaruh dana kompensasi, dana bagi hasil dan pajak daerah terhadap belanja modal di kabupaten atau kota di Provinsi Banten. Waktu pengamatan dalam riset ini selama enam tahun yaitu 2015 hingga 2020. Objek pengamatan dalam penelitian ini yaitu seluruh kabupaten atau kota di Provinsi Banten. Teknik pengambilan sampel yang digunakan adalah intensional (purposif) sampling. Penelitian ini menggunakan data sekunder yang didapat dari Laporan Realisasi Anggaran Pendapatan dan Belanja Daerah. Metode analisis menggunakan analisis regresi data panel. Hasil riset menerangkan bahwa Dana Perimbangan mempengaruhi secara negatif dan tidak signifikan terhadap belanja modal, Dana Bagi Hasil mempengaruhi belanja modal secara negatif dan signifikan, Pajak Daerah mempengaruhi belanja modal secara positif dan tidak signifikan, sedangkan sisa lebih pembiayaan anggaran mempengaruhi secara negatif dan signifikan terhadap Belanja Modal, Sisa Lebih Pembiayaan Anggaran mampu memoderasi dan mampu memperkuat atau memperlemah hubungan antara Dana Perimbangan terhadap Belanja Modal, Sisa Lebih Pembiayaan Anggaran mampu memoderasi dan mampu memperkuat hubungan antara Dana Bagi Hasil terhadap Belanja Modal, dan Sisa Lebih Pembiayaan Anggaran tidak mampu memoderasi dan tidak mampu memperkuat atau memperlemah hubungan antara Pajak Daerah terhadap Belanja Modal.
\end{abstract}

Kata Kunci: Belanja Modal, Dana Perimbangan, Dana Bagi Hasil, Pajak Daerah, dan Sisa Lebih Pembiayaan Anggaran

\section{Pendahuluan}

Ketika pemerintah Indonesia dihadapkan pada krisis moneter pada paruh awal tahun 1997, para ekonom gagal dan sebagian besar kekuasaan manajemen dialihkan ke daerah. Pemotongan anggaran negara untuk mendanai pembangunan dan pelayanan publik.
Distribusi pembangunan yang ada dan alokasi belanja modal yang belum optimal, yang menyebabkan adanya keterlambatan pembangunan yang dimiliki oleh daerah, dapat mendorong penerapan otonomi daerah. Pemerintah memiliki kewenangan untuk mengurus dan mengatur wilayahnya sendiri sesuai dengan keinginan penduduk. 
Jenis kompensasi finansial adalah dana kompensasi yang disediakan oleh kantor pusat perusahaan. Uang tersebut berasal dari pendapatan APBN yang dialokasikan untuk memenuhi kebutuhan daerah sebagai bagian dari proses desentralisasi, dengan tujuan untuk menciptakan keseimbangan keuangan antara pemerintah pusat dan daerah (Ferdiansyah dkk, 2018).

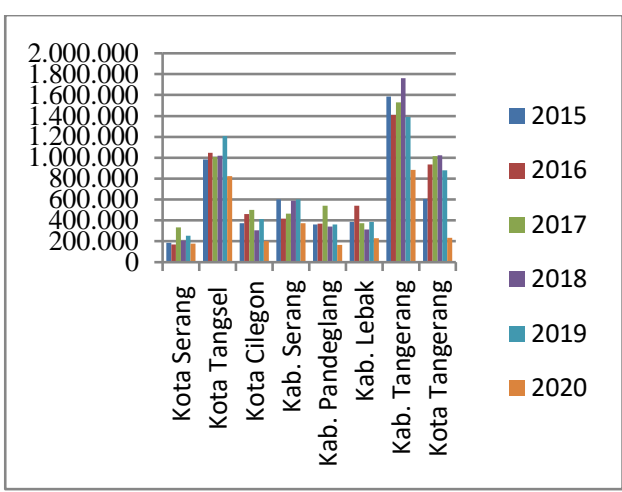

\section{Gambar 1 \\ Realisasi Belanja Modal Kabupaten/Kota Provinsi Banten Tahun 2015-2020}

Realisasi belanja modal kabupaten/kota di Provinsi Banten dari tahun 2015 sampai dengan tahun 2020 dapat dilihat pada grafik 1. Akibat dampak Virus Covid-19, belanja modal seluruh kabupaten/kota di Provinsi Banten mengalami penurunan pada tahun 2020. Hal ini berpengaruh signifikan terhadap Provinsi Banten Kabupaten/Kota, karena semakin tinggi realisasi penanaman modal di suatu daerah menunjukkan semakin makmur dan sejahtera masyarakat tersebut. Kabupaten/kota dengan realisasi belanja modal yang tinggi menunjukkan bahwa daerah memiliki dana yang cukup dan telah merespon himbauan pemerintah pusat dengan mengalokasikan belanja modal di atas batas minimal, dan belanja modal tersebut berdampak pada penyediaan pelayanan publik yang lebih baik. Penyediaan pelayanan publik yang baik akan mempengaruhi kelancaran kegiatan ekonomi lokal.

Namun faktanya, Pemerintah Daerah Banten kurang mengupayakan untuk peningkatan penerimaan daerah yang nantinya akan dialokasikan bukan untuk pembangunan infrastruktur publik melainkan untuk belanja rutin lainnya yang masih kurang produktif ditambah lagi untuk biaya penanganan virus Covid-19. Hal ini sejalan dengan penelitian yang dilakukan oleh Abbas, D. S., Eksandy, A., Hidayat, I., \& Larasati, N (2020) bahwa Pemerintah Daerah Banten lebih banyak memfokuskan pendapatan daerah untuk pengeluaran belanja operasi, dibandingkan untuk pengeluaran belanja modal.

Menurut Anny Widiasmara (2019), belanja modal adalah pengeluaran yang dilakukan dalam rangka pembentukan modal yang menambah aktiva tetap atau aktiva lain yang memberikan manfaat lebih dari satu periode akuntansi, termasuk pengeluaran untuk pemeliharaan, pemeliharaan atau peningkatan masa manfaat, peningkatan kapasitas, dan kualitas aset.

Dana perimbangan adalah uang yang berasal dari pendapatan APBN yang disalurkan ke daerah dalam rangka mendukung kebutuhan daerah dalam rangka pelaksanaan desentralisasi, dengan tujuan untuk mencapai keseimbangan keuangan antara pemerintah pusat dan pemerintah daerah (Ferdiansyah dkk, 2018).

Temuan penelitian Ferdiansyah et al (2018) menunjukkan bahwa Dana Perimbangan memiliki pengaruh positif dan substansial terhadap Belanja Modal, berbeda dengan temuan penelitian Ardhani 2011) yang menunjukkan bahwa Dana Perimbangan memiliki pengaruh positif tetapi dapat diabaikan.

Menurut Heliyanto (2016), Dana Bagi Hasil adalah dana APBN yang diberikan kepada daerah berdasarkan angka persentase untuk membiayai kebutuhan daerah dalam rangka pelaksanaan desentralisasi. Pajak dan aset daerah 
digunakan untuk mendanai dana bagi hasil (DBH). Dana Bagi Hasil (DBH) juga merupakan sumber bantuan bagi pemerintah daerah dalam penyediaan sarana dan prasarana umum, dan digunakan untuk infrastruktur daerah melalui belanja modal.

Hasil penelitian Azhar dan Abubakar (2020) menyimpulkan bahwa dana bagi hasil (DBH) berpengaruh positif dan substansial terhadap belanja modal, bertentangan dengan kesimpulan Anggia Ayu (2018) bahwa dana bagi hasil (DBH) berpengaruh negatif dan berpengaruh signifikan terhadap belanja modal.

Menurut Sarjono et al. (2018), Pajak Daerah adalah iuran wajib kepada daerah yang terutang oleh orang pribadi atau badan dan digunakan untuk meningkatkan kemakmuran rakyat dan diamanatkan oleh undang-undang.

Surya Asih dan Irawan (2015) menyimpulkan bahwa pajak daerah berpengaruh positif dan substansial terhadap belanja modal, berbeda dengan Maria Valencia dan Nur Handayani (2015) yang menyimpulkan bahwa pajak daerah berpengaruh negatif dan signifikan terhadap belanja modal. Menurut Simbolon et al. (2020), Sisa Pembiayaan Anggaran (SiLPA) merupakan penerimaan daerah yang berasal dari selisih kas tahun anggaran sebelumnya. Sedangkan sisa dana anggaran surplus adalah selisih uang yang diperoleh dengan mempertanggungjawabkan penerimaan dan pengeluaran anggaran daerah untuk satu periode, menurut Peraturan Menteri Dalam Negeri (Permendagri) Nomor 13 Tahun 2006.

Penelitian Yohannes dan Erwin

(2020) menyimpulkan bahwa sisa pembiayaan anggaran yang tersisa berpengaruh positif dan signifikan terhadap belanja modal, berbeda dengan penelitian Hanif Muftiandi (2020) yang menyatakan bahwa sisa pembiayaan anggaran berpengaruh negatif dan signifikan terhadap belanja modal.

The Banten province administration should put more emphasis on capital spending so that it is more helpful and can give the best service to the people. In order for the community to flourish, proper public amenities must be available.

\section{Manfaat Penelitian \\ Manfaat Bagi Akademik}

Hasil penelitian ini diharapkan dapat memperkaya konsep atau teori yang menyongsong perkembangan ilmu pengetahuan sehingga penelitian ini diharapkan dapat memberikan informasi bagi rancangan penelitian selanjutnya.

\section{Manfaat Bagi Pemerintah}

Hasil penelitian ini diharapkan dapat menjadi bukti empiris mengenai penerapan sistem perimbangan daerah yang sedang berjalan dan bisa dijadikan acuan dalam menetapkan kebijakan selanjutnya.

\section{Tinjauan Pustaka}

\section{Teori Stewardship}

Donaldson \& Davis (1991) menggambarkan teori stewardship sebagai teori yang didasarkan pada perilaku dan premis. Stewardship theory adalah teori yang menjelaskan situasi di mana manajer didorong oleh tujuan hasil utama mereka untuk kepentingan organisasi daripada oleh ambisi individu. Dapat disimpulkan bahwa teori ini pada dasarnya menggambarkan bagaimana Pemerintah Daerah, sebagai organisasi yang dapat dipercaya, dapat bertindak dan memprioritaskan kepentingan publik melalui program kerjanya dengan benar. Dengan ruang lingkup seperti pembuatan laporan pertanggungjawaban atas pemenuhan dana APBD yang ditetapkan oleh badan, pencapaian tujuan badan tersebut dapat meningkatkan kualitas pelayanan publik dan kesejahteraan masyarakat dapat terlaksana dengan baik.

Sehingga dapat digunakan dalam model penelitian ini, yang dapat dinikmati dengan beberapa faktor independen yaitu pajak daerah, dan variabel dependen yaitu 
belanja modal, serta variabel moderasi yaitu sisa pembiayaan anggaran tambahan (Expenditure et al., 2020). Menurut teori stewardship, terdapat kaitan yang kuat antara kinerja organisasi dengan kesenangan pemilik, dan pemerintah akan melakukan yang terbaik dalam menjalankan pemerintahan dan kepentingan publik untuk kesejahteraan masyarakat.

\section{Teori Stakeholder}

Teori pemangku kepentingan adalah teori yang mendefinisikan pihak mana yang bertanggung jawab; itu ditemukan oleh Freeman \& Reed (1983). Gagasan ini juga menjelaskan mengapa ada aspek dengan melibatkan banyak pihak, termasuk anggota semua organisasi, pemerintah, dan masyarakat sekitar dari konteks yang beragam. Apakah kelompok memiliki kekuasaan atau tidak dalam masyarakat, baik secara langsung maupun tidak langsung. Sebuah pilihan dan kinerja suatu kelompok atau orang memiliki dampak besar pada keberadaan suatu proses dalam organisasi. Stakeholder adalah orang atau kelompok yang berkepentingan terhadap sesuatu. Sehingga dalam penelitian ini dapat digunakan model yang berinteraksi dengan variabel independen, seperti Dana Bagi Hasil dan Dana Perimbangan, yang termasuk dalam Stakeholder Theory.

The government is required to play a part in advancing the Banten area by developing and investigating all existing potentials and controlling methods as a source of Banten regional revenue, as well as being able to decide capital in a reasonable, efficient, and effective manner.

\section{Kerangka Teoritis dan Hipotesis}

\section{Pengaruh Dana Perimbangan Terhadap Belanja Modal}

Dana perimbangan adalah transfer dana dari pemerintah pusat kepada pemerintah daerah yang dimaksudkan untuk menutup kesenjangan fiskal dan menjamin pemerataan kapasitas fiskal antar daerah, sehingga pemerintah daerah dapat lebih mandiri dalam menjalankan fungsi dan tugasnya untuk melayani masyarakat. masyarakat. bagi pemerintah daerah untuk mendukung belanja daerah Provinsi Banten.

Dana Perimbangan dapat dilihat sebagai akibat dari penyerahan kewenangan dari pemerintah pusat kepada pemerintah daerah, yang menyiratkan bahwa harus ada transaksi transfer yang besar dalam anggaran pemerintah pusat kepada pemerintah daerah. Namun, masih terdapat kekurangan dalam rasio dana terhadap modal-pengeluaran. Melalui belanja modal, Pemerintah Daerah diharapkan mampu memberikan pelayanan publik yang memadai dan baik kepada masyarakat.

Menurut uraian tersebut, ada kaitannya dengan Stakeholder Theory yang menyatakan bahwa pemerintah sebagai pemegang kekuasaan harus menonjolkan unsur kepentingan rakyat sebagai Stakeholder. Menurut Wulansari dan Ferdian (2015), dana perimbangan berpengaruh positif dan substansial terhadap belanja modal, namun penelitian yang dilakukan oleh Ardhani (2011) menunjukkan bahwa Dana Perimbangan berpengaruh positif namun dapat diabaikan.

$\mathrm{H}_{1}$ : Apakah dana perimbangan berpengaruh terhadap belanja modal

\section{Pengaruh Dana Bagi Hasil (DBH) Terhadap Belanja Modal}

Dana Bagi Hasil merupakan dana perimbangan yang diberikan oleh pemerintah pusat untuk membantu pemerintah daerah dalam melaksanakan segala urusan dalam pemerintahannya, salah satunya adalah pelaksanaan program yang bersinggungan langsung dengan masyarakat umum yaitu peningkatan pelayanan publik melalui pembangunan dan peningkatan sarana dan prasarana di kawasan tersebut.

Upaya yang dilakukan oleh pemerintah bertujuan untuk memberikan pelayanan yang terbaik kepada masyarakat. 
DBH tersebut kemudian direalisasikan oleh pemerintah daerah melalui belanja modal. Namun demikian, masih terdapat kesenjangan pemanfaatan DBH untuk belanja modal di beberapa daerah sehingga pertumbuhannya tidak merata. Akibatnya, DBH menjadi tidak berguna dan tidak efisien. Keadaan demikian harus segera diperbaiki agar pemerintah daerah dapat memberikan pelayanan publik yang memadai kepada penduduk melalui adanya Belanja Modal. Berdasarkan definisi tersebut, ada kaitannya dengan Stakeholder Theory yang menyatakan bahwa pemerintah sebagai pemegang kekuasaan harus mengutamakan unsur kepentingan rakyat sebagai Stakeholder.

Berdasarkan penelitian Bauw et al. (2014), Dana Bagi Hasil berpengaruh positif dan substansial terhadap Belanja Modal, namun penelitian Anggia Ayu (2018) menyatakan bahwa Dana Bagi Hasil berpengaruh negatif dan signifikan, dengan demikian hipotesis yang diajukan adalah sebagai berikut:

$\mathrm{H}_{2}$ : Apakah dana bagi hasil berpengaruh terhadap belanja modal.

\section{Pengaruh Pajak Daerah terhadap belanja modal}

Pajak daerah sebagian besar berasal dari hasil operasi sektor industri di berbagai jenis perusahaan yang ada di wilayah tersebut. Perkembangan sektor industri daerah berpengaruh terhadap naik atau turunnya penerimaan pajak daerah. Pada kenyataannya, tingkat optimalisasi sektor industri ditentukan oleh belanja modal.

Belanja modal harus dialokasikan sebaik mungkin untuk mendorong pembangunan ekonomi nasional. Ini menjelaskan, sebagian, keterkaitan Stewardship Theory, yang selalu menekankan hubungan yang kuat antara pencapaian tujuan organisasi dan kebahagiaan masyarakat. Hal ini dapat ditunjukkan dengan realisasi penerimaan Pajak Daerah yang dapat mempengaruhi pembangunan dan peningkatan pembangunan di suatu daerah agar dapat bermanfaat bagi masyarakat.

Pajak daerah memiliki pengaruh yang menguntungkan dan substansial terhadap belanja modal, demikian temuan penelitian yang dilakukan oleh Hasbullah (2017). Namun, temuan penelitian ini bertentangan dengan temuan Ramlan et al. (2016), yang menemukan bahwa pajak kota memiliki pengaruh negatif dan substansial terhadap belanja modal, oleh karena itu hipotesis dibingkai sebagai berikut:

$\mathrm{H}_{3}$ : Apakah pajak daerah berpengaruh terhadap belanja modal.

Pengaruh Sisa Lebih Pembiayaan Anggaran (SiLPA) Memoderasi Dana Perimbangan terhadap Belanja Modal

SILPA terdiri dari kelebihan penerimaan PAD, kelebihan dana perimbangan pendapatan daerah lainnya yang sah, penerimaan pembiayaan kewajiban kepada pihak ketiga, dan sisa uang operasional tindak lanjut sampai dengan akhir tahun belum terselesaikan. Akibatnya, semakin besar SiLPA, semakin tinggi Dana Perimbangan, yang juga akan berpengaruh pada peningkatan alokasi Belanja Modal. Hal ini akan berdampak pada peningkatan kesejahteraan masyarakat.

Kajian ini difokuskan pada keterkaitan dengan Stewardship Theory, yang dapat ditunjukkan melalui realisasi pendapatan daerah yang dapat meningkatkan SiLPA dan juga bermanfaat bagi masyarakat.

Menurut Marnaek (2018), hubungan Dana Perimbangan berpengaruh positif dan substansial serta mampu memoderasi Belanja Modal dengan SiLPA sebagai moderator. Berdasarkan temuan penjelasan, hipotesis berikut dapat dikembangkan:

H4: Apakah sisa lebih pembiayaan anggaran dapat memoderasi dana perimbangan terhadap belanja modal. 
Pengaruh Sisa Lebih Pembiayaan Anggaran Memoderasi Dana Bagi Hasil terhadap Belanja Modal.

Menurut Maulana (2017), Dana Bagi Hasil (DBH) adalah dukungan yang disalurkan ke daerah berdasarkan angka persentase untuk mendanai kebutuhan daerah dalam rangka mencapai desentralisasi. Dana Bagi Hasil merupakan penunjang pembangunan daerah yang membantu melengkapi sarana dan prasarana umum serta prasarana daerah. SiLPA dapat mempengaruhi dampak Dana Bagi Hasil terhadap Belanja Modal. Akibatnya, SiLPA berpotensi mengatur atau berdampak pada keterkaitan antara Dana Bagi Hasil dan Belanja Modal. Berdasarkan definisi tersebut, ada keterkaitan dengan Teori Stakeholder, bahwa Pemerintah Daerah sebagai pemegang kekuasaan harus menonjolkan unsur kepentingan rakyat sebagai Stakeholder dalam hal penyediaan sarana dan prasarana publik.

Menurut penelitian Cahyaning (2018), Dana Bagi Hasil berpengaruh positif dan substansial terhadap Belanja Modal, dengan SiLPA bertindak sebagai moderator. Hipotesis berikut dapat dibentuk berdasarkan temuan penjelasan ini:

H5: Apakah sisa lebih pembiayaan anggaran dapat memoderasi dana bagi hasil terhadap belanja modal.

\section{Pengaruh Sisa Lebih Pembiayaan Memoderasi Pajak Daerah Terhadap Belanja Modal}

Menurut Purnama Arif (2014), SiLPA adalah kelebihan anggaran pendapatan dan pengeluaran yang direalisasikan selama satu kuartal fiskal. Melampaui tujuan SiLPA akibat melebihi target pendapatan daerah dan efisiensi anggaran sangat diantisipasi. Hal ini terkait dengan Pajak Daerah; jika Pajak Daerah naik, SiLPA dan Belanja Modal akan naik juga. Kenaikan Belanja Modal akan berpengaruh pada penyediaan fasilitas publik yang lebih baik bagi masyarakat dan kesejahteraan masyarakat.
Teori Stewardship penelitian ini menggambarkan keberadaan pemerintah daerah dalam menjalankan kegiatan masyarakat. Penelitian sebelumnya Arthur Simanjuntak (2019) menunjukkan bahwa Pajak Daerah mempengaruhi Belanja Modal, dengan SiLPA bertindak sebagai moderator.

Berdasarkan penjelasan-penjelasan tersebut, maka dapat diambil kesimpulan sebagai berikut:

H6: Apakah sisa lebih pembiayaan anggaran dapat memoderasi pajak daerah terhadap belanja modal

\section{Metode Penelitian}

\section{Jenis Penelitian}

Jenis riset ini merupakan penelitian kuantitatif, metode kuantitatif diartikan sebagai penelitian yang berlandaskan pada filsafat positivism yang dilakukan mempelajari pada populasi ataupun ilustrasi/sampel tertentu. Metode analisis yang digunakan yaitu, regresi data panel dengan bantuan program Eviews 9. Data yang digunakan dalam penelitian ini adalah data sekunder berupa laporan realisasi APBD yang terdaftar di Badan Pusat Statistik (BPS) periode 2015-2020.

\section{Tempat dan Waktu Penelitian}

Tempat dan waktu penelitian ini dilakukan di Badan Pusat Statistik dan Dirjen Jenderal Perimbangan Keuangan (DJPK) dengan mengunduh data laporan realisasi anggaran melalui website www.djpk.depkeu.go.id Objek penelitian akan difokuskan pada Kabupaten/Kota di Provinsi Banten yang terdaftar di Badan Pusat Statistik dan DJPK tahun 2015-2020.

\section{Definisi Operasional Penelitian Variabel Dependen}

Variabel dependen yaitu variabel yang dipengaruhi atau yang menjadi sebab akibat, karena adanya variabel independen dan variabel pemoderasi. Variabel dependen dalam penelitian ini adalah 
belanja modal, belanja modal merupakan unsur dari Belanja Daerah yang dilakukan oleh Pemerintah Daerah diantaranya untuk pembangunan dan perbaikan sektor pendidikan, kesehatan, transportasi dan infrastruktur sehingga masyarakat juga menikmati manfaat dari pembangunan daerah tersebut (Ayem, S \& Pratama, 2018).

\section{Variabel Independen}

Variabel independen adalah variabel yang mempengaruhi atau yang menjadi sebab perubahan variabel dependen. Variabel independen dalam penelitian ini adalah Dana Perimbangan, DBH, dan Pajak Daerah.

Dana perimbangan adalah uang yang berasal dari pendapatan APBN yang disalurkan ke daerah dalam rangka mendukung kebutuhan daerah dalam rangka pelaksanaan desentralisasi, dengan tujuan untuk mencapai keseimbangan keuangan antara pemerintah pusat dan pemerintah daerah Ferdiansyah dkk (2018).

Menurut Heliyanto (2016), Dana Bagi Hasil adalah dana APBN yang diberikan kepada daerah berdasarkan angka persentase untuk membiayai kebutuhan daerah dalam rangka pelaksanaan desentralisasi. Pajak dan aset daerah digunakan untuk mendanai dana bagi hasil (DBH). Dana Bagi Hasil (DBH) juga merupakan sumber bantuan bagi pemerintah daerah dalam penyediaan sarana dan prasarana umum, dan digunakan untuk infrastruktur daerah melalui belanja modal. Sarjono et al. (2018), Pajak Daerah adalah iuran wajib kepada daerah yang terutang oleh orang pribadi atau badan dan digunakan untuk meningkatkan kemakmuran rakyat dan diamanatkan oleh undang-undang.

\section{Variabel Pemoderasi}

Variabel pemoderasi yaitu variabel yang mampu memperkuat atau memperlemah hubungan langsung antara variabel independen dengan variabel dependen.
Variabel pemoderasi dalam penelitian ini adalah Sisa Lebih Pembiayaan Anggaran

Menurut (Simbolon et al., 2020),

Sisa Pembiayaan Anggaran (SiLPA) merupakan penerimaan daerah yang berasal dari selisih kas tahun anggaran sebelumnya. Sedangkan sisa dana anggaran surplus (SiLPA) adalah selisih uang yang diperoleh dengan mempertanggungjawabkan hasil penerimaan dan pengeluaran anggaran daerah untuk satu periode.

\section{Populasi dan Sampel \\ Populasi}

Populasi dalam penelitian ini adalah Pemerintah Kabupaten/Kota yang berada di Provinsi Banten yang terdaftar di Badan Pusat Statistik (BPS) dan DJPK. Periode penelitian ini mencakup data pada tahun 2015-2020 agar lebih mencerminkan kondisi saat ini.

\section{Sampel}

Pengambilan sampel dalam penelitian ini metode yang dipakai yaitu metode non probability sampling serta menggunakan teknik purposive sampling. Kriteria pertimbangan dalam penelitian ini adalah sebagai berikut, kabupaten atau kota di Provinsi Banten yang menyampaikan Laporan Realisasi APBD pada tahun 20152020 melalui situs resmi yaitu www.djpk.kemenkeu.go.id/portal/data/apbd bandten.

\section{Teknik Pengumpulan Data}

Dalam penelitian ini data yang digunakan adalah data sekunder. Metode yang digunakan adalah metode Library Research dengan teknik dokumentasi. Sumber data yang diperoleh dari laporan realisasi anggaran Pemerintah Kab/Kota di Provinsi Banten yang terdaftar di Badan Pusat Statistik dan DJPK untuk periode 20152020.

\section{Metode Analisis Data}

Penelitian ini menggunakan metode analisis kuantitatif, yaitu dimana data yang 
digunakan dalam penelitian ini berbentuk angka. Analisis yang digunakan dalam penelitian ini adalah analisis regresi data panel. Analisis regresi data panel adalah gabungan antara data time series dengan data cross section, dimana banyak obyek penelitian yang diamati pada dua periode waktu atau lebih yang diindikasikan dengan penggunaan beberapa periode data time series.

Langkah pengujian data adalah mencoba mengidentifikasi model yang benar sehingga dapat digunakan pada tahap analisis regresi selanjutnya, dalam pengujian ini untuk menentukan jenis analisis regresi yang dapat dimanfaatkan melalui tahap pengujian model, yaitu sebagai berikut :

Tabel 2

Kesimpulan Model

\begin{tabular}{llll}
\hline No & \multicolumn{2}{c}{ Pengujian } & Model \\
\hline 1. & Chow & CEM VS & FEM \\
& Test & FEM & \\
2. & Hausman & FEM VS & FEM \\
& Test & REM & \\
3. & Lagrange & REM VS & REM \\
& Multiplier & CEM & \\
\hline
\end{tabular}

Sumber data diolah peneliti, 2021

\section{Hasil Penelitian dan Pembahasan}

Berdasarkan pengamatan pada tabel 2, dapat disimpulkan bahwa model FEM lebih cocok untuk menganalisis hubungan antar komponen dalam variabel eksogen dan endogen, serta variabel moderasi. Tabel di bawah ini berisi deskripsi data statistik dari variabel yang digunakan

\section{Tabel 3}

\section{Hasil Uji Statistik Deskriptif}

\begin{tabular}{cccccc}
\hline & BM & DP & DBH & PD & PE \\
\hline Mean & 26.95833 & 27.69417 & 25.32167 & 26.66583 & 26.57271 \\
Median & 26.86000 & 27.83000 & 25.13500 & 26.72500 & 26.48000 \\
Maximum & 28.20000 & 28.17000 & 26.38000 & 32.39000 & 28.36000 \\
Minimum & 25.82000 & 26.59000 & 24.34000 & 21.97000 & 25.18000 \\
Std. Dev. & 0.665200 & 0.449188 & 0.533596 & 1.758106 & 0.820168 \\
Skewness & 0.103764 & -0.830434 & 0.341523 & 0.247843 & 0.229977 \\
Kurtosis & 1.996914 & 2.698115 & 1.921421 & 4.329965 & 2.314508 \\
\hline Observations & 48 & 48 & 48 & 48 & 48 \\
\hline \multicolumn{5}{l}{ Sumber data diolah peneliti, 2021} \\
\end{tabular}




\section{Belanja Modal}

Nilai BM minimum adalah 25.86000, dan nilai tertinggi adalah 28.20000 , sesuai dengan hasil uji statistik deskriptif pada tabel 3. Temuan ini menunjukkan bahwa nilai BM Kabupaten/Kota di Provinsi Banten yang menjadi subjek penelitian, tinggi. Nilainya berkisar antara 25.82000 hingga 28.20000, dengan mean (Mean) 26.95833 dan standar deviasi 0.665200 . Kabupaten Tangerang memiliki nilai BM tertinggi pada tahun 2018 sebesar 28,20, sedangkan Kabupaten Pandeglang memiliki nilai terendah pada tahun 2020 sebesar 25,82 .

\section{Dana Perimbangan}

Nilai Dana Perimbangan minimal adalah 26.59000, dan nilai tertinggi adalah 28.17000, menurut hasil uji statistik deskriptif pada tabel 3. Berdasarkan temuan tersebut, nilai Dana Perimbangan Kabupaten/Kota di Provinsi Banten subjek penelitian ini, berjalan dari 26.59000 sampai 28.17000, dengan nilai rata-rata (Mean) 27,69417 dan standar deviasi 0,449188. Nilai Dana Perimbangan terbesar di Kabupaten Tangerang pada tahun 2018 sebesar 26,59, sedangkan nilai terendah sebesar 28,17 di Kabupaten Pandeglang pada tahun 2020 .

\section{Dana Bagi Hasil}

Dana Bagi Hasil memiliki nilai minimum 24.34000 dan nilai maksimum 26.38000, sesuai dengan temuan uji statistik deskriptif pada tabel 3. Berdasarkan temuan tersebut, nilai Dana Bagi Hasil Kabupaten/Kota di Banten Provinsi, subjek penelitian, bervariasi dari 24.34000 hingga 26.38000 , dengan nilai rata-rata 25.32167 dan standar deviasi 0,533596. Kabupaten Tangerang memiliki nilai Dana Bagi Hasil terbesar pada tahun 2018, yaitu sebesar 26,38, sedangkan Kabupaten Pandeglang memiliki nilai terendah pada tahun 2020 yaitu sebesar 24,34.

\section{Pajak Daerah}

Nilai Pajak Daerah minimal sebesar 21.97000, dan nilai tertinggi sebesar 32.39.000, sesuai dengan temuan uji statistik deskriptif pada tabel 3 . Berdasarkan temuan tersebut, nilai Pajak Kabupaten/Kota di Provinsi Banten yang menjadi subjek penelitian ini, berjalan dari 21.97000 menjadi 32.39000 , dengan nilai rata-rata (Mean) sebesar 26.66583 dan standar deviasi 1.758106. Kabupaten Tangerang memiliki nilai Pajak Daerah tertinggi pada tahun 2018 sebesar 32,39, sedangkan Kabupaten Pandeglang memiliki nilai Pajak Daerah terendah pada tahun 2020 sebesar 21,97.

\section{SiLPA}

Hasil uji statistik deskriptif pada tabel 3 menunjukkan bahwa sisa dana anggaran memiliki nilai minimum 25.18000 dan nilai maksimum 28.36000. Berdasarkan temuan tersebut, nilai sisa Pembiayaan APBD Kabupaten/Kota di Provinsi Banten yang menjadi subjek penelitian ini bervariasi antara 25.18000 sampai dengan 28.36000, dengan nilai rata-rata 26.57271 dan standar deviasi 0.820168. Kabupaten Tangerang memiliki nilai sisa Pembiayaan Anggaran terbesar pada tahun 2018, sebesar 28,36, sedangkan Kabupaten Pandeglang memiliki nilai terendah pada tahun 2020, yaitu sebesar 25,18 .

Tahap selanjutnya adalah pengujian asumsi klasik, yang tidak dapat dilakukan untuk semua model hasil yang akan digunakan setelah tahap pengujian. Pengujian asumsi klasik hanya digunakan dalam pendugaan model analisis untuk model regresi yang menggunakan metode OLS. Common Effect Model (CEM) dan Fixed Effect Model (FEM) keduanya menganalisis model regresi menggunakan metode Ordinary Least Squares (OLS) (FEM). Sebagai konsekuensi dari temuan pengujian model regresi, ditentukan bahwa model Fixed Effect Model (FEM) layak untuk digunakan. Dengan demikian, dalam 
penelitian ini regresi akan dievaluasi untuk

Tabel 4

Hasil Uji Multikolinearitas

\begin{tabular}{|c|c|c|c|c|c|}
\hline & BM & DP & DBH & PD & SLPA \\
\hline $\mathrm{BM}$ & 1.000000 & 0.314082 & 0.641253 & 0.644253 & 0.779915 \\
\hline DP & 0.314082 & 1.000000 & 0.181175 & 0.067687 & 0.331157 \\
\hline DBH & 0.641253 & 0.181175 & 1.000000 & 0.673102 & 0.580718 \\
\hline PD & 0.644253 & 0.067687 & 0.673102 & 1.000000 & 0.687472 \\
\hline SILPA & 0.779915 & 0.331157 & 0.580718 & 0.687472 & 1.000000 \\
\hline Breusch-Pagan LM & 0.0689 & & & & \\
\hline R-squared & 0.858903 & & & & \\
\hline Adjusted R-squared & 0.799044 & & & & \\
\hline F-statistic & 14.34875 & & & & \\
\hline Prob(F-statistic) & 0.000000 & & & & \\
\hline
\end{tabular}

Sumber: data diolah, eviews, 2021

Temuan korelasi setelah uji multikolinearitas menunjukkan bahwa tidak ada data yang memiliki nilai koefisien lebih tinggi, bahkan semua koefisien variabelnya kurang dari 0,8. Akibatnya, temuan pengujian tidak menunjukkan tanda-tanda multikolinearitas karena nilai koefisien antara variabel penelitian independen yang digunakan kurang dari 0,8 (Eksandy \& Heriyanto, 2017). multikolinearitas dan heteroskedastisitas Berdasarkan hasil pengujian pada tabel 4 menunjukkan bahwa nilainya adalah 0,0689 ,

menunjukkan bahwa nilainya lebih besar dari 0,05 , menunjukkan bahwa model regresi yang dipilih layak dan tidak menunjukkan gejala heterosis.

Berdasarkan hasil uji $\mathrm{F}$ diperoleh nilai F-statistik sebesar 14.34875, sedangkan F-tabel yang diperoleh sebesar, dengan kriteria taraf 5\%, df1(5-1)=4 dan df2 (48-5) $=43$, sehingga dapat disimpulkan bahwa nilai F-statistik 14,34875 > F tabel 2,43 dan nilai Prob (Fstatistik) 0,000000 sesuai dengan 0,05, Selanjutnya hasil uji Adjusted R-squared sebesar 0,799044 menunjukkan bahwa variasi dinamika naik turun belanja modal dapat dijelaskan oleh variabel eksogen dengan nilai kontribusi sebesar $79,90 \%$, sedangkan sisanya sebesar 20,10\% dijelaskan oleh variabel lain yang tidak diamati dalam diskusi ini. 


\section{Pembahasan}

Tabel 5

Hasil Pengujian Regresi Data Panel

\begin{tabular}{|c|c|c|c|c|c|}
\hline Hyp. & Hypothesis Statement & $\begin{array}{l}\text { Coef. } \\
\text { Value }\end{array}$ & $\mathbf{P}>|\mathbf{z}|$ & Sig & Model \\
\hline 1. & $\begin{array}{l}\text { Dana Perimbangan tidak berpengaruh terhadap } \\
\text { belanja modal }\end{array}$ & -4.273995 & $\begin{array}{l}\text { Hipotesis } \\
\text { ditolak }\end{array}$ & - & $\begin{array}{ll}\text { BM } & = \\
609.4267 & -\end{array}$ \\
\hline 2. & $\begin{array}{l}\text { Dana Bagi Hasil berpengaruh negatif terhadap } \\
\text { belanja modal. }\end{array}$ & -19.19810 & $\begin{array}{l}\text { Hipotesis } \\
\text { diterima }\end{array}$ & $\sqrt{ }$ & $\begin{array}{l}4.273995 \text { DP } \\
-19.19810\end{array}$ \\
\hline 3. & $\begin{array}{l}\text { Pajak Daerah tidak berpengaruh terhadap belanja } \\
\text { modal }\end{array}$ & 0.413653 & $\begin{array}{l}\text { Hipotesis } \\
\text { ditolak }\end{array}$ & - & $\begin{array}{lr}\text { DBH } & + \\
0.413653 & \text { PD }\end{array}$ \\
\hline 4. & $\begin{array}{l}\text { Sisa Lebih Pembiayaan Anggaran tidak dapat } \\
\text { memoderasi antara Dana Perimbangan terhadap } \\
\text { Belanja Modal. }\end{array}$ & 0.165208 & $\begin{array}{l}\text { Hipotesis } \\
\text { ditolak }\end{array}$ & - & $\begin{array}{l}+\quad 0.165208 \\
\text { DP*SILPA } \\
+\quad 0.727864\end{array}$ \\
\hline 5. & $\begin{array}{l}\text { Sisa Lebih Pembiayaan } \\
\text { memoderasi positif antara } \\
\text { mangaran } \\
\text { terhadap Belanja Modal. }\end{array}$ & 0.727864 & $\begin{array}{l}\text { Hipotesis } \\
\text { diterima }\end{array}$ & $\sqrt{ }$ & $\begin{array}{l}\text { DBH*SILP } \\
\text { A }-0.014463 \\
\text { PD*SILPA }\end{array}$ \\
\hline 6. & $\begin{array}{l}\text { Sisa Lebih Pembiayaan Anggaran tidak dapat } \\
\text { memoderasi antara Pajak Daerah terhadap Belanja } \\
\text { Modal }\end{array}$ & -0.014463 & $\begin{array}{l}\text { Hipotesis } \\
\text { diterima }\end{array}$ & - & + zit \\
\hline
\end{tabular}

\section{Pengaruh Dana Perimbangan terhadap Belanja Modal}

Dalam penelitian ini hipotesis diuji untuk melihat apakah dana perimbangan berpengaruh negatif dan dapat diabaikan terhadap belanja modal. Berdasarkan hasil pengujian pada tabel 5, variabel dana perimbangan memiliki nilai $\mathrm{t}$-statistik sebesar $(-0,680941)$, nilai $t$ tabel sebesar (2,01669), dan Prob. 0,0056 sig 0,05. Hal ini menunjukkan bahwa dana bagi hasil memiliki dampak negatif dan tidak signifikan terhadap belanja modal (BM). Akibatnya, hipotesis pertama, bahwa dana perimbangan berpengaruh negatif dan tidak signifikan terhadap belanja modal, ditolak.

Menurut uraian tersebut, ada kaitannya dengan Stakeholder Theory yang menyatakan bahwa pemerintah sebagai pemegang kekuasaan harus menonjolkan unsur kepentingan rakyat sebagai Stakeholder. Hal ini bertentangan dengan penelitian Wulansari dan Ferdian (2015) yang mengklaim bahwa hasil penelitiannya menunjukkan bahwa dana perimbangan memiliki pengaruh positif dan substansial terhadap belanja modal, namun penelitian Ardhani (2011) menunjukkan bahwa dana perimbangan memiliki pengaruh positif tetapi tidak signifikan.

\section{Pengaruh Dana Bagi Hasil terhadap Belanja Modal}

Tujuan pengujian hipotesis penelitian ini adalah untuk melihat apakah dana bagi hasil berpengaruh negatif dan signifikan terhadap belanja modal. Berdasarkan hasil pengujian pada tabel 5, variabel bagi hasil memiliki nilai t-statistik (-2.965280), nilai t-tabel (2.01669), dan Prob. 0,0056 sig 0,05. Hal ini menunjukkan bahwa dana bagi hasil memiliki dampak negatif yang cukup besar terhadap belanja modal (BM). Dengan demikian hipotesis kedua yang menyatakan bahwa dana bagi hasil berpengaruh negatif dan substansial terhadap belanja modal, diterima.

Hal ini terlihat di Kota Tangerang dan Kota Tangerang Selatan, dimana realisasi Dana Bagi Hasil tumbuh stabil dari tahun 2015 hingga 2018. Kenaikan realisasi DBH berdampak pada optimalisasi penerimaan DBH yang selanjutnya akan dimanfaatkan untuk upaya meningkatkan alokasi belanja modal dalam rangka memberikan pelayanan yang lebih baik. 
Karena fasilitas umum dapat diterima, individu dapat bergerak dengan aman dan menyenangkan.

Temuan pengujian ini sesuai dengan temuan Azhar dan Abubakar (2020) yang menemukan bahwa dana bagi hasil berpengaruh positif dan substansial terhadap belanja modal. Namun hal ini bertolak belakang dengan temuan Anggia Ayu (2018) yang menemukan bahwa dana bagi hasil memiliki pengaruh negatif dan dapat diabaikan terhadap belanja modal. Berdasarkan definisi tersebut, ada kaitannya dengan Teori Stakeholder yang menyatakan bahwa pemerintah sebagai pemegang kekuasaan harus mengutamakan unsur kepentingan rakyat sebagai Stakeholder.

\section{Pengaruh Pajak Daerah terhadap Belanja Modal}

Tujuan pengujian hipotesis penelitian ini adalah untuk melihat apakah pajak kota memiliki pengaruh terhadap belanja modal. Berdasarkan ringkasan tabel temuan pada tabel 5 diketahui bahwa variabel regional memiliki nilai t-statistik sebesar 0,376765 > t-value 2,01669 dan a Prob. 0,7088 > sig 0,05 . Hal ini menunjukkan bahwa pajak kota memiliki dampak yang menguntungkan tetapi kecil pada belanja modal (BM). Diperkirakan bahwa pajak kota memiliki dampak yang menguntungkan tetapi tidak signifikan terhadap belanja modal.

Memang, kabupaten/kota yang menerima pungutan pajak daerah dalam jumlah yang signifikan lebih cenderung memiliki ketergantungan belanja modal. Besarnya pajak daerah yang dipungut oleh Pemerintah Daerah akan membantu Pemerintah Daerah melaksanakan kewajibannya untuk menyalurkan atau mengalokasikan dana pajak ke sektor belanja modal dengan lebih cepat. Oleh karena itu, pembangunan di berbagai elemen fasilitas di kawasan ini akan terlaksana untuk kemaslahatan dan kesejahteraan rakyat.

Temuan ini sejalan dengan temuan
Surya Asih dan Irawan (2015) yang menemukan bahwa pajak kota berpengaruh positif namun kecil terhadap belanja modal. Berbeda dengan temuan Maria Valencia, yang menyatakan bahwa terdapat dampak negatif dan dapat diabaikan terhadap belanja modal. Berdasarkan definisi tersebut, ada keterkaitan dengan Stewardship Theory yang menyatakan bahwa keberadaan pemerintah daerah harus untuk kepentingan warganya.

\section{Pengaruh SiLPA Dalam Memoderasi Dana Perimbangan terhadap Belanja Modal}

Variabel SiLPA tidak mampu mengatur, memperkuat, atau melemahkan Dana Perimbangan Belanja Modal Provinsi Banten antara tahun 2015 sampai dengan tahun 2020. Hal ini dibuktikan dengan tStatistik DP*SiLPA sebesar $(0,686502) \mathrm{t}$ Tabel (2,01669) dan Prob. 0,4972, menunjukkan bahwa SiLPA tidak dapat mengubah atau meningkatkan Dana Perimbangan terhadap Belanja Modal.

Temuan penelitian Ferdiansyah et al (2018) menunjukkan bahwa Dana Perimbangan memiliki pengaruh positif dan substansial terhadap Belanja Modal, berbeda dengan temuan Ardhani (2011) penelitian yang menunjukkan bahwa Dana Perimbangan memiliki pengaruh positif tetapi dapat diabaikan. Menurut uraian tersebut terdapat keterkaitan dengan Teori Stakeholder yaitu Pemerintah sebagai pemegang kekuasaan dan unsur Kepentingan Rakyat sebagai Stakeholder.

\section{Pengaruh SiLPA dalam Memoderasi Dana Bagi Hasil Terhadap Belanja Modal \\ Variabel SiLPA berpotensi untuk mengatur dan memperkuat Dana Bagi Hasil Belanja Modal Provinsi Banten dari tahun 2015 sampai dengan tahun 2020. Hal ini dibuktikan dengan t-Statistik DBH*SiLPA sebesar (2.988583) t Tabel (2.01669) dan Prob. 0,0053, menunjukkan bahwa SiLPA dapat memoderasi dan meningkatkan Dana}


Bagi Hasil Belanja Modal.

Hal ini bertolak belakang dengan penelitian yang dilakukan oleh Rana Fathinah Ananda (2019), yang mengklaim bahwa SiLPA tidak mampu mengendalikan Dana Bagi Hasil atas Belanja Modal. Sementara itu, studi yang dilakukan oleh Anggia Ayu (2018) menunjukkan bahwa SiLPA dapat membatasi Dana Bagi Hasil untuk Belanja Modal.

Menurut uraian tersebut, ada kaitannya dengan Teori Stakeholder, dimana pemerintah sebagai pemegang kekuasaan harus menonjolkan unsur kepentingan rakyat sebagai Stakeholder.

\section{Pengaruh Sisa Lebih Pembiayaan} Anggaran dalam Memoderasi Pajak Daerah Terhadap Belanja Modal

Pada periode 2015-2020, variabel SiLPA tidak dapat mengubah Pajak Daerah atas Belanja Modal di Provinsi Banten. Hal ini ditunjukkan oleh t-Statistik PD*SiLPA dari $(-0,354977) \mathrm{t}$ Tabel $(-2,01669)$ dan Prob. 00.7249, menunjukkan bahwa SiLPA tidak mampu memoderasi atau memperkuat Pajak Belanja Modal Daerah.

Hal ini bertentangan dengan penelitian Surya Asih (2015) yang mengklaim bahwa SiLPA dapat mengurangi Pajak Daerah atas Belanja Modal. Berbeda dengan temuan Erdi dan Octaviani (2015), Pertumbuhan Ekonomi tidak mampu mengatur Pajak Daerah atas Belanja Modal.

Berdasarkan definisi ini, ada kaitan dengan Stewardship Theory, yang menyatakan bahwa tujuan pemerintah kota adalah untuk meningkatkan infrastruktur publik untuk kepentingan warganya.

\section{Simpulan dan Saran}

\section{Simpulan}

Berdasarkan hasil analisis data panel penelitian ini dan pengujian hipotesis, maka dapat disimpulkan bahwa variabel Dana Perimbangan (DP) dan Pajak Daerah (PD) tidak berpengaruh terhadap Belanja Modal.
Namun berbeda dengan variabel Dana Bagi Hasil (DBH) yang berpengaruh negatif dan substansial terhadap Belanja Modal dalam penelitian ini. Selanjutnya variabel Sisa Pembiayaan Anggaran (SiLPA) tidak berpengaruh terhadap hubungan Dana Perimbangan dengan Belanja Modal. Demikian pula variabel sisa dana anggaran (SiLPA) tidak dapat menambah atau mengurangi hubungan antara Pajak Daerah dan Belanja Modal. Sisa Pembiayaan Anggaran (SiLPA), di sisi lain, berpotensi meningkatkan keterkaitan antara Dana Bagi Hasil dan Belanja Modal.

\section{Saran}

Bagi Penelitian yang Akan Datang

a. Menambah periode penelitian yang lebih panjang agar hasil penelitian dapat menggeneralisasi dan lebih baik.

b. Memperbanyak daerah atau objek penelitian sehingga sampel yang diperoleh juga lebih banyak dan data yang didapatkan juga menjadi lebih akurat.

\section{Bagi Pemerintah}

a. Pemerintah daerah harus lebih cermat dalam memanfaatkan dana yang dialokasikan dari pemerintah pusat maupun dana yang berasal dari daerah. Jika hal tersebut terpenuhi, maka aset yang dimiliki oleh pemerintah daerah akan semakin bertambah sesuai dengan kebutuhan masyarakat guna mensejahterakan publik.

b. Diharapkan pemerintah dapat menggali sumber pendapatan guna mengalokasikan lebih besar terhadap belanja modal, dengan adanya pendapatan yang lebih besar diharapkan pemerintah tidak lagi memiliki ketergantungan terhadap pemerintah pusat dan berguna untuk mensejahterakan masyarakat. 


\section{Keterbatasan}

Ada beberapa kekurangan dan keterbatasan dalam penelitian penulis. Kedepannya batasan-batasan yang ingin penulis sampaikan dapat menjadi acuan bagi penelitian-penelitian selanjutnya yang dapat dibandingkan, sehingga hasil penelitianpenelitian yang akan datang dapat lebih baik dan sempurna.

Adapun keterbatasan penelitian ialah penelitian ini hanya dilakukan selama enam tahun, dari 2015 hingga 2020, dengan sampel kecil delapan kabupaten/kota, hasilnya mungkin tidak dapat dipercaya dan mungkin tidak mencerminkan realitas jangka panjang. Selanjutnya, analisis ini hanya menggunakan tiga faktor independen yaitu Pembiayaan Kelebihan Anggaran, Dana Bagi Hasil, dan Pajak Daerah, satu variabel dependen, Belanja Modal, dan satu variabel moderasi, Pertumbuhan Ekonomi.

Agar penelitian ini dapat lebih baik kedepannya, maka berdasarkan keterbatasan penelitian diatas, peneliti memberikan rekomendasi sebagai berikut: Pemerintah daerah harus lebih berhati-hati dalam menggunakan dana dari pemerintah pusat dan juga kas dari daerah. Jika ini terpenuhi, aset yang dikuasai oleh pemerintah daerah akan tumbuh sesuai dengan kebutuhan masyarakat untuk kepentingan umum. Dan hal ini dimaksudkan agar pemerintah dapat menelusuri sumber-sumber penerimaan agar dapat lebih dikhususkan untuk Belanja Modal. Dengan lebih banyak uang, diyakini pemerintah tidak akan lagi bergantung pada pemerintah pusat dan akan bermanfaat bagi kesejahteraan masyarakat.

\section{Daftar Pustaka}

Abbas, D. S., Eksandy, A., Hidayat, I., \& Larasati, N. (2020). Belanja Modal Di Provinsi Banten Beserta FaktorFaktor Yang Mempengaruhinya. Financial: Jurnal Akuntansi, 6(2), 154-168.
Arthur Simanjuntak. (2019). Pengaruh Pajak Daerah, Retribusi Daerah, Dana Alokasi Umum, Dan Dana Alokasi Khusus Terhadap Belanja Daerah. Jurnal Manajemen, 5(1), 45-52.

Asih, S., \& Irawan. (2018). Pengaruh Kontribusi Pajak Daerah, Pendapatan Asli Daerah, Retribusi Daerah Dan Dana Bagi Hasil Pajak Terhadap Belanja Daerah Dengan Pertumbuhan Ekonomi Sebagai Variabel Moderating Pemerintah Kabupaten Dan Kota. Jurnal Akuntansi Bisnis \& Publik, 9(1), 177-191.

Bakhrudin, B. (2020, September). Pengaruh Pad, Dau, Dana Perimbangan Dan Dbh Terhadap Belanja Modal Studi Kasus Kabupaten/Kota Di Jawa Timur. In Prosiding Seminar Nasional Akuntansi, Manajemen, Dan Keuangan (Vol. 1, No. 1).

Cahyaning, S. (2018). Pengaruh Pendapatan Asli Daerah, Dana Alokasi Umum Dan Dana Bagi Hasil Terhadap Alokasi Belanja Modal Dengan Pertumbuhan Ekonomi Sebagai Variabel Moderating Pada Pemerintah Daerah Kabupaten/Kota Provinsi Jawa Timur Tahun 20132015. Jurnal Ilmu Ekonomi Terapan, 3(1), $1-38$ https://doi.org/10.20473/jiet.v3i1.787 Eksandy, A., Hakim, M. Z., \& Ekawati, E. (2019). Pengaruh Pendapatan Asli Daerah, Dana Alokasi Umum Dan Dana Alokasi Khusus Terhadap Belanja Modal (Pada Pemerintah Provinsi Banten Periode 2011-2015). Competitive Jurnal Akuntansi Dan Keuangan, 2(2), 85-94.

Fitria, N. (2021). Pengaruh Dana Alokasi Umum, Dana Alokasi Khusus Dan Sisa Lebih Perhitungan Anggaran Terhadap Belanja Daerah Kabupaten/Kota Di Aceh. Etd Unsyiah.

Hasbullah, R. (2017). Pengaruh Pajak Daerah, Retribusi Daerah, Dana Alokasi Umum, Dana Alokasi 
Khusus, Dan Pertumbuhan Ekonomi Terhadap Pengalokasian Belanja Modal (Studi Empiris pada Pemerintah Kabupaten/Kota Di Jawa Tengah periode 2012-2014. Universitas Muhammadiyah Surakarta.

Nainggolan, B. R. M., \& Hantono, H. (2018). Pengaruh Pendapatan Asli Daerah Dan Dana Perimbangan Terhadap Belanja Modal Dengan Sisa Lebih Perhitungan Anggaran Sebagai Variabel Moderasi Pada Pemerintah Kota Dan Kabupaten Provinsi Sumatera Utara. Jurnal Akrab Juara, 3(1), 178-190.

Sanjaya, D., \& Helmy, H. (2021). Pengaruh Pendapatan Asli Daerah (PAD), Kekayaan Daerah, Sisa Lebih Pembiayaan Anggaran (SILPA) terhadap Belanja Modal dengan Petumbuhan Ekonomi sebagai Variabel Moderasi Pada Pemerintah Provinsi Se-Indonesia periode 20152019. Jurnal Eksplorasi Akuntansi, 3(2), 450-469.

Simbolon, Y. C., Maksum, A., \& Abubakar, E. (2020). Pengaruh PAD, SiLPA, DAU, DAK dan DBH Terhadap Alokasi Belanja Modal: Studi Kasus Pada Pemerintah Kabupaten/Kota Provinsi Sumatera Utara, Bangka Belitung, Kepulauan Riau dan Bengkulu periode 2012-2018. Jurnal Sains Sosio Humaniora, 4(2), 826839.

https://doi.org/10.22437/jssh.v4i2.115 46

Wahyudi, M. V. (2015). Pengaruh Pajak, Retribusi Daerah, Dau, Dan Dak Terhadap Alokasi Anggaran Belanja Modal. Ilmu \& Riset Akuntansi, 4(11), 2-17.

Waskito, W., Zuhrotun, Z., \& Rusherlisyani, R. (2019). Pengaruh Pertumbuhan Ekonomi, Pendapatan Asli Daerah, Dana Alokasi Umum, Dana Alokasi Khusus, dan Dana Bagi
Hasil Terhadap Belanja Modal (Studi pada Pemerintah Kabupaten \& Pemerintah Kota di Provinsi Aceh). Reviu Akuntansi Dan Bisnis Indonesia, 3(2), 220-238. https://doi.org/10.18196/rab.030247 